\title{
INSTASTORY PERILAKU KONSUMEN DI ERA NEW NORMAL
}

\author{
I Made Hariyoga ${ }^{1}$, I Gusti Ngurah Putra Suryanata ${ }^{2}$ \\ 1,2 Universitas Pendidikan Nasional \\ E-mail: 2yoga.ari491@gmail.com, 2ngurahputrasuryanata@undiknas.ac.id
}

\begin{abstract}
The aims of this study to determine consumer behavior and the stages of purchasing decisions due to Instastory marketing carried out by Griya Bakery \& Griya Florist in the new normal era. The research method used is a qualitative method. Researchers conducted interviews with selected informants using the "accidental sampling" technique. The informants in this study were 12 people (1 owner and 11 consumers). The stages in data analysis include data collection, data reduction, data display, and conclusion drawing / verification. The theory of consumer behavior and purchasing decisions by Kotler and Armstrong (2008) is used as the basis for this study. Based on the research results, it can be concluded that psychological factors have the greatest influence on Instastory marketing in shaping consumer behavior in the new normal era. The stages of the consumer purchasing decision making process are various. Most informants pass through the need Introduction - Purchase Decision - Post Purchase stage.
\end{abstract}

Keywords: Instastory, Consumer Behavior, Purchase Decision

\begin{abstract}
ABSTRAK
Penelitian ini bertujuan untuk mengetahui perilaku konsumen dan tahapan keputusan pembelian akibat pemasaran Instastory yang dilakukan oleh Griya Bakery \& Griya Florist di era new normal. Metode penelitian yang digunakan adalah metode kualitatif. Peneliti melakukan wawancara kepada informan yang dipilih dengan menggunakan teknik "accidental sampling". Informan dalam penelitian ini berjumlah 12 orang ( 1 orang owner dan 11 orang konsumen). Tahapan dalam analisis data meliputi pengumpulan data (data collection), reduksi data (data reduction), penyajian data (data display), serta penarikan kesimpulan dan verifikasi (conclusion drawing/verivication). Teori perilaku konsumen dan keputusan pembelian oleh Kotler dan Armstrong (2008) digunakan sebagai landasan dalam penelitian ini. Berdasarkan hasil penelitian maka dapat disimpulkan bahwa faktor psikologi memberikan pengaruh paling besar terhadap pemasaran Instastory dalam membentuk perilaku konsumen di era new normal. Tahapan proses pengambilan keputusan pembelian konsumen ditemukan beragam. Informan paling banyak melewati tahapan Pengenalan Kebutuhan - Keputusan Pembelian - Pasca Pembelian
\end{abstract}

Kata Kunci: Instastory, Perilaku Konsumen, Keputusan Pembelian 


\section{PENDAHULUAN}

\section{Latar Belakang}

Media sosial menjadi tempat untuk melakukan aktivitas sosial di dunia maya. Berdasarkan data dari We Are Sosial, Hootsuite 2020, menetapkan 10 media sosial yang paling sering digunakan pada tahun 2020, diantaranya yaitu Youtube, WhatsApp, Facebook, Instagram, Twitter, Line, FB Messenger, LinkdIn, Pinterest, dan Wechat (Jayani, 2020). Instagram menduduki posisi ke empat media sosial yang paling sering digunakan.

Banyak fitur menarik dan canggih yang ditawarkan dalam media sosial Instagram. Salah satunya adalah Instagram story atau yang sering disingkat dengan Instastory. Data yang dikutip dari databoks.katadata.co.id, Statista tahun 2017, memperlihatkan bahwa pada bulan April 2017, pengguna harian Instagram story terus meroket hingga melampaui aplikasi sejenis yaitu Snapchat. Sekitar 200 juta akun menggunakan Instagram story setiap harinya, sedangkan Snapchat diprediksi berada pada angka 170 juta akun (Statista, 2017).

Instastory telah menyaring target pasar khususnya generasi millennial. Peluang ini dimanfaatkan oleh para pelaku usaha untuk membuat promosi bisnis melalui Instastory. Dikutip dari artikel tekno.kompas.com, lebih dari dua juta pengiklan mengandalkan Instastory untuk mempromosikan produk dan jasa yang mereka tawarkan (Bohang, 2019). Dilanisir dari antaranews.com, menyebutkan bahwa Indonesia adalah salah satu yang memanfaatkan konten Instastory di dunia sejak fitur tersebut diluncurkan sekitar 10 bulan yang lalu. Sepertiga dari konten yang paling sering dilihat berasal dari sektor bisnis. Saat ini secara global 8 juta akun di Instagram digunakan sebagai akun bisnis (Andarningtyas, 2017). Berdasarkan data tersebut, menunjukkan bahwa Instastory banyak dipilih sebagai strategi pemasaran dalam menggiring para calon konsumen untuk memengaruhi perilaku konsumen.

Covid-19 yang muncul pada akhir tahun 2019 menyebabkan terjadinya banyak perubahan di segala bidang, termasuk bidang ekonomi. World Health Organization dan pemerintahan di berbagai negara telah mendeklarasikan tatanan baru untuk hidup berdampingan dengan covid-19, dengan gagasan "new normal" (Lassa, 2020). Masa new normal dampak dari pandemi covid-19 merupakan tatanan kebiasaan baru yang diputuskan oleh pemerintah dengan mengutamakan penerapan protokol kesehatan covid-19.

Era new normal tidak begitu saja mengembalikan kondisi kehidupan masyarakat kembali seperti sedia kala. Daya beli terhadap barang dan jasa sangat kurang. Hal ini menandakan adanya perubahan pola perilaku konsumen pada era new normal dalam mengonsumsi suatu produk. Dilihat dari sudut pandang ekonomi dan bisnis, new normal menggeser model bisnis menjadi serba digital dan bergantung pada teknologi (Perdana et al., 2020).

Perubahan perilaku konsumen juga harus dapat dipahami dalam kondisi sekarang ini dimana masyarakat sangat berhati-hati dalam memilih dan mengonsumsi suatu produk. Peluang media sosial Instagram melalui fitur Instastory digunakan oleh pelaku usaha sebagai senjata untuk memengaruhi perilaku konsumen pada era new normal. Melalui media sosial 
Instagram dan pemanfaatan jasa influencer terbukti memberikan dampak positif bagi penjualan perusahaan (Handika et al., 2018).

Pemasaran melalui Instagram sangat membantu pelaku usaha. Kegiatan pemasaran mulai berpindah dari konvensional menuju digital. Akibat pemasaran Instagram tersebut menyebabkan terjadinya perubahan pola perilaku konsumen di era Marketing 4.0 dari 4A (Aware, Attitude, Act dan Act Again) menjadi 5A (Aware, Appeal, Ask, Act, dan Advocate) (Indah Kencana Putri, 2019).

Strategi pemasaran di era new normal juga memiliki perbedaan yang mendasar dengan pemasaran sebelumnya di era covid-19 karena harus memperhatikan protokol kesehatan yang dianjurkan oleh pemerintah. Saat ini, pelaku bisnis tidak hanya berfokus pada produk saja, tetapi juga berfokus pada layanan yang diberikan kepada konsumen. Bagaimana perusahaan tersebut dapat memberikan rasa aman dan nyaman terhadap konsumennya pada saat mengonsumsi produk tersebut melalui bauran pemasaran dengan melibatkan 4 (empat) elemen yaitu product, price, place, dan promotion yang telah disesuaikan dengan kondisi lingkungan saat ini (Barokah et al., 2020).

Hasil penelitian terdahulu sudah banyak membuktikan hasil positif penggunaan media sosial Instagram dengan memanfaatkan jasa influencer serta menerapkan strategi bauran pemasaran yang melibatkan 4 (empat) elemen yaitu product, price, place, dan promotion.

Namun dalam kondisi new normal, tentu adanya perbedaan perilaku konsumen sebelum pandemi covid-19 dengan perilaku konsumen di era new normal. Banyak jenis usaha yang mengalami kegagalan. Terjadi perubahan perilaku konsumen dalam membeli suatu produk. Konsumen lebih mengutamakan membeli kebutuhan pokok dibandingkan kebutuhan yang lainnya. Akan tetapi ada pula jenis usaha yang menjual kebutuhan tersier dapat berkembang pesat di era new normal. Brand usaha tersebut yaitu Griya Bakery \& Griya Florist. Target informan dalam penelitian ini yaitu pemilik usaha dan dan konsumen yang tinggal di wilayah Denpasar. Hal ini dipilih karena Ibu Kota Provinsi Bali ini memiliki penduduk yang heterogen dimana berasal dari berbagai daerah dengan jenis pekerjaan, penghasilan, budaya, dan kebiasaan yang beragam. Griya Bakery \& Griya Florist menggunakan Instastory sebagai media pemasaran. Lalu bagaimana Instastory mampu memengaruhi perilaku konsumen di era new normal hingga para konsumen memutuskan untuk melakukan pembelian produk? Perilaku konsumen seperti apa saja yang muncul dan bagaimana tahapan proses keputusan pembelian produk Griya Bakery \& Griya Florist?

\section{Identifikasi Masalah}

Berdasarkan latar belakang diatas, penelitian ini mengidentifikasi bagaimana perilaku konsumen khususnya keputusan pembelian yang muncul akibat pemasaran Instastory di era new normal.

\section{Rumusan Masalah}

Adapun rumusan masalah yang ingin diteliti adalah bagaimana Instastory Griya Bakery \& Griya Florist memengaruhi prilaku konsumen dan keputusan pembelian pada era new normal? 


\section{LANDASAN TEORI}

\section{Perilaku Konsumen}

Perilaku konsumen merupakan tahapan-tahapan langkah yang ditempuh dan dilakukan oleh seseorang/individual atau kelompok orang dalam rangka memenuhi kebutuhan dan keinginannya (Mulyadi, 2013). Menurut Engel et al dalam buku Suryani yang berjudul Perilaku Konsumen Implikasi Pada Strategi Pemasaran, pemahaman terhadap perilaku konsumen mencangkup pemahaman terhadap tindakan yang langsung yang dilakukan konsumen dalam mendapatkan, mengonsumsi dan menghabiskan produk dan jasa, termasuk proses keputusan yang mendahului dan mengikuti tindakan-tindakan tersebut (Suryani, 2008). Fahmi mendefinisikan perilaku konsumen sebagai studi tentang unit pembelian (buying units) dan proses pertukaran yang melibatkan perolehan, konsumsi, dan pembuangan barang, jasa, pengalaman, serta ide-ide (Fahmi, 2016).

Terdapat beberapa karakteristik yang dapat memengaruhi perilaku konsumen. Kotler dan Amstrong mengemukakan bahwa pembelian konsumen sangat dipengaruhi oleh karakteristik budaya, sosial, pribadi, dan psikologis (Kotler \& Armstrong, 2008).

\section{Keputusan Pembelian}

Keputusan pembelian konsumen merupakan tahapan proses akhir dari serangkaian tahapan proses yang terjadi pada perilaku konsumen (Mulyadi, 2013). Fahmi menyatakan bahwa keputusan konsumen merupakan tindakan konsumen dalam memutuskan sebuah produk yang dianggap menjadi solusi dari kebutuhan dan keinginan konsumen tersebut (Fahmi, 2016). Kotler dan Amstrong mengemukakan bahwa proses pembelian dimulai jauh sebelum pembelian sesungguhnya dan berlanjut dalam waktu yang lama setelah pembelian (Kotler \& Armstrong, 2008).

Proses pengambilan keputusan pembelian dibagi menjadi lima tahap yaitu pengenalan kebutuhan, pencarian informasi, evaluasi alternatif, keputusan pembelian, dan perilaku pasca pembelian (Kotler \& Armstrong, 2008).

\section{METODE PENELITIAN}

Metode penelitian yang digunakan oleh peneliti adalah metode kualitatif. Menurut Sugiyono, metode penelitian merupakan cara ilmiah untuk mendapatkan data dengan tujuan dan kegunaan tertentu (Sugiyono, 2019). Pemilihan informan dilakukan dengan teknik accidental sampling. Teknik pengambilan sampel ini digunakan untuk memperoleh sumber data dengan menentukan informan secara kebetulan. Informan dalam penelitian ini sebanyak 12 orang yang terdiri dari 1 orang pemilik usaha dan 11 orang konsumen Griya Bakery \& Griya Florist. Data diambil dari para informan dengan memberikan pemahaman, interpretasi serta informasi yang dibutuhkan sesuai dengan fenomena dalam penelitian ini. Alasan lebih lanjut digunakannya metode penelitian kualitatif karena peneliti ingin melakukan pengamatan dan mendapatkan informasi langsung dari sumber data melalui wawancara mendalam, observasi dan dokumentasi data.

Penelitian ini juga menggunakan metode dokumentasi. Sugiyono mengemukakan bahwa metode dokumentasi merupakan sebuah metode dengan mengumpulkan dokumen berupa catatan seperti tulisan, gambar, atau karya - karya monumental dari seseorang (Sugiyono, 2017). 


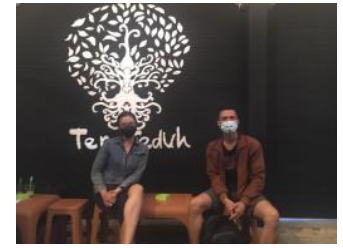

Gambar 1. Wawancara dengan Pemilik Usaha

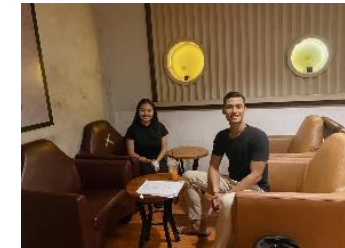

Gambar 2. Wawancara dengan Konsumen

Data disajikan secara deskriptif kualitatif dan bersifat apa adanya yang berasal dari pengamatan dan analisis serta memperoleh hasil yang lebih menekankan makna. Untuk menguji keabsahan data, peneliti menggunakan teknik triangulasi. Pertama adalah triangulasi sumber. Sumber dalam penelitian ini yaitu pemilik usaha dan juga konsumen. Kemudian triangulasi teknik dimana peneliti melakukan wawancara dengan informan serta melakukan observasi terhadap Instastory Griya Bakery \& Griya Florist. Terakhir yaitu triangulasi waktu. Peneliti melakukan wawancara dalam waktu dan kondisi yang berbeda

\section{PEMBAHASAN}

\section{Konsumen Mengetahui Produk}

Instagram juga memiliki fitur baru yang saat ini sangatlah diminati yaitu bernama snapgram (Handika et al., 2018). Hasil data penelitian menunjukkan bahwa para informan mengetahui produk Griya Bakery \& Griya Florist dari platform media sosial Instagram melalui fitur Instastory. Seluruh konsumen Griya Bakery \& Griya Florist yang berjumlah 11 orang mengatakan mereka mengetahui Griya Bakery \& Griya Florist berawal dari Instastory. Para informan mengetahui produk setelah melihat unggahan Instastory yang diunggah pemilik usaha dalam akun pribadi miliknya @dayuprema. Tidak hanya melalui Instagram @ dayuprema, informan lainnya mengetahui produk dari akun lain yang diikuti. Akun tersebut biasanya merupakan pelanggan Griya Bakery \& Griya Florist yang juga membuat unggahan dalam bentuk konten Instastory.

\section{Perilaku Konsumen Dipengaruhi oleh Faktor Budaya}

Budaya adalah penentu keinginan dan tingkah laku yang tercermin dari cara hidup, kebiasaan dan tradisi dalam permintaan akan bermacam-macam barang dan jasa (Syafirah et al., 2017). Hasil penelitian ini mendapatkan dua faktor yang memengaruhi perilaku konsumen yang masuk dalam katagori faktor budaya yaitu budaya 1. Perayaan moment spesial dan budaya 2. Sikap saling menolong.

\section{1) Perayaan Moment Spesial}

Suatu moment dirayakan karena hanya berlangsung satu tahun sekali seperti perayaan ulang tahun, hari Valentine, hari Ibu, Idul Fitri dan perayaan lainnya. Orang-orang juga sering merayakan perayaan sekali seumur hidup seperti sidang skripsi atau tesis, yudisium, dan wisuda. Hal inilah yang menjadikan suatu moment memiliki nilai yang sangat spesial bagi mereka yang merayakannya. Perayaan moment tersebut menjadi motivasi pembelian yang berawal dari melihat unggahan konten Instastory. Adanya motivasi akan mendorong konsumen ke arah keputusan pembelian (Keren \& Sulistiono, 2019). Instastory Griya Bakery \& Griya Florist hadir memberikan solusi untuk memenuhi kebutuhan pelanggan yang sedang membutuhkan hadiah dalam merayakan moment spesial para konsumen.

\section{2) Sikap Saling Menolong}

Bentuk usaha yang dihadirkan oleh Griya Bakery \& Griya Florist melalui kontenkonten Instastory berhasil mengambil hati konsumen. Berdasarkan hasil penelitian, konsumen 
tersebut memesan produk dengan alasan ingin membantu usaha ditengah kondisi sulit. Konsumen ingin membantu pemilik usaha Griya Bakery \& Griya Florist setelah melihat unggahan Instastory @dayuprema. Informan lainnya juga menyatakan membeli produk dan kemudian membuat unggahan Instastory pada akun pribadi miliknya untuk membantu mempromosikan produk Griya Bakery \& Griya Florist melalui media sosial Instagram.

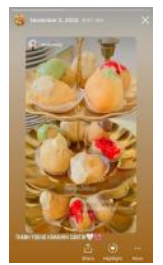

\section{Gambar 3. Unggahan Instastory Konsumen}

\section{Perilaku Konsumen Dipengaruhi oleh Faktor Sosial}

Aktivitas sosial bisa berupa aktivitas sosial konsumen di dalam jejaring sosial maupun interaksi sosial secara langsung di dunia nyata. Berdasarkan hasil penelitian, peneliti mengklasifikasikan faktor sosial menjadi empat kode yaitu 1. Aktivitas media sosial, 2. Review konsumen dalam Instastory, 3. Hubungan sosial, serta 4. Peran dan status.

\section{1) Aktivitas Media Sosial}

Peneliti mendapatkan hasil bahwa para informan memiliki keinginan untuk membeli setelah melihat Instastory yang diunggah oleh @dayuprema ataupun konsumen lainnya. Setelah terpapar oleh Instastory Griya Bakery \& Griya Florist, calon konsumen merasa penasaran dan kemudian tertarik serta memutuskan untuk membeli. Konsumen dapat langsung memesan produk dengan cara me-reply unggahan Instastory yang diunggah oleh akun pemilik usaha@dayuprema. Media sosial saat ini menjadi salah satu media yang dapat digunakan untuk sarana komunikasi (Sholeh et al., 2019).

\section{2) Review Konsumen dalam Instastory}

Salah satu strategi yang diterapkan pemilik usaha dalam menciptakan sebuah konten Instastory yaitu dengan menampilkan berbagai macam review. Jumlah review yang banyak membuat konsumen yang awalnya masih merasa ragu menjadi yakin dan memutuskan untuk membeli. Review juga menimbulkan rasa penasaran terhadap produk yang ditawarkan. Berbagai review tersebut dipotong dan digabungkan dalam satu konten Instastory sehingga konsumen dapat merasa lebih yakin untuk membeli. Review sangat berguna untuk membantu konsumen dalam membuat keputusan pembelian (M. Febriana \& Yulianto, 2018).

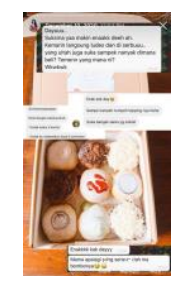

\section{Gambar 4. Instastory Review Konsumen}

\section{3) Hubungan Sosial}

Hubungan sosial dalam penelitian ini dikelompokkan menjadi dua yaitu hubungan sosial dengan teman dan hubungan sosial dengan keluarga. 
Teman, generasi milenial juga melibatkan teman sebaya (peer influence) pada pengambilan keputusan dalam pembelian (Wiridjati \& Roesman, 2018). Dalam penelitian ini, informan terpengaruh setelah mendapat informasi atau rekomendasi dari teman mereka yang sudah pernah membeli produk Griya Bakery \& Griya Florist. Ketika mendapatkan komentar secara langsung dari teman tentang produk yang sudah pernah dibeli, konsumen akan lebih mudah percaya. Keputusan pembelian lebih cepat terjadi. Selain itu, para informan juga memengaruhi teman mereka untuk membeli produk melalui interaksi di media sosial.

Keluarga, anggota keluarga juga berperan dalam mengambil keputusan pembelian (Towoliu \& Tumbuan, 2017). Sikap pembelian yang dipengaruhi oleh keluarga dapat berupa rekomendasi atau keyakinan keputusan untuk membeli produk, keinginan dari salah seorang keluarga untuk membeli produk, atau keinginan konsumen untuk membelikan anggota keluarganya produk Griya Bakery \& Griya Florist. Anak-anak juga mempunyai pengaruh kuat pada keputusan pembelian keluarga (Kotler \& Armstrong, 2008).

\section{4) Peran dan Status}

Kotler dan Armstrong berpendapat bahwa orang biasanya memilih produk yang sesuai dengan peran dan status mereka (Kotler \& Armstrong, 2008). Konsumen dalam perannya sebagai anggota keluarga membeli donat bomboloni untuk dibagikan kepada anggota keluarganya. Peran dan status lainnya yaitu posisi sebagai seorang pacar. Seorang pacar tentu ingin membuat pasangannya bahagia. Keputusan yang diambil adalah dengan membelikan produk Griya Bakery \& Griya Florist berupa donat bomboloni ataupun bouqete bunga.

\section{Perilaku Konsumen Dipengaruhi oleh Faktor Pribadi}

Keputusan membeli dipengaruhi oleh karakteristik pribadi seperti umur dan tahap daur hidup, pekerjaan, situasi ekonomi, gaya hidup serta kepribadian konsumen (Syafirah et al., 2017). Peneliti mengklasifikasikan hasil penelitian terhadap faktor pribadi menjadi tiga kode utama yaitu 1. Karakteristik dan kepribadian, 2. Situasi ekonomi konsumen, dan 3. Gaya hidup.

\section{1) Karakteristik dan Kepribadian}

Kepribadian setiap orang yang berbeda-beda memengaruhi perilaku pembelinya (Kotler \& Armstrong, 2008). Berdasarkan hasil penelitian, peneliti mendapatkan hasil karakteristik dan kepribadian dilihat dari sisi konsumen dan juga dilihat dari sisi pemilik usaha.

Konsumen, beberapa konsumen yang membeli donat bomboloni di Griya Bakery merupakan tipe orang yang memang pecinta donat atau suka makan makanan yang manismanis. Di sisi lain, konsumen Griya Florist memutuskan membeli bunga karena konsumen itu sendiri ataupun orang yang akan diberikan bunga merupakan tipe orang yang juga menyukai bunga. Instagram yang menonjolkan sharing foto terbukti punya korelasi kuat dalam memengaruhi minat beli konsumen (Indika \& Jovita, 2017).

Pemilik usaha, konten Instagram yang menyenangkan dapat menarik perhatian followers untuk mau membaca informasi (Hansudoh et al., 2021). Beberapa konten memperlihatkan bagaimana kepribadian dan kerja keras pemilik usaha dalam menjalankan usaha Griya Bakery \& Griya Florist. Perjuangan yang ditampilkan dalam Instastory membuat konsumen lebih menghargai produk yang dijual. Konsumen juga menilai pemilik usaha sangat ramah dalam memberikan respon dan feedback kepada konsumen. Hal ini membuat konsumen merasa nyaman dan senang untuk belanja di Griya Bakery \& Griya Florist. 


\section{2) Situasi Ekonomi Konsumen}

Masyarakat telah merasakan bahwa pandemi corona membawa dampak yang luar biasa, terutama perekonomian (Taib \& Supriana, 2020). Beberapa konsumen mempertimbangkan harga terlebih dahulu sebelum membeli produk. Harga produk Griya Bakery \& Griya Florist dinilai masih sesuai dengan budget sehingga konsumen kemudian melanjutkan untuk membeli produk. Hal yang berbeda disampaikan oleh informan lainnya. Informan ini mengungkapkan bahwa mereka sudah mengatur keuangan khususnya di masa new normal. Mereka sudah menentukan porsi-porsi dari setiap kebutuhan yang ingin dibeli termasuk kebutuhan tersier seperti untuk membeli produk dari Griya Bakery \& Griya Florist.

\section{3) Gaya Hidup}

Gaya hidup menggambarkan kepribadian seseorang yang berinteraksi dengan lingkungannya (Luthfianto, 2017). Hasil gaya hidup dalam penelitian ini diklasifikasikan menjadi dua yaitu membuat Instastory pasca pembelian dan mengikuti trend.

Membuat Instastory, pemasaran melalui media sosial Instagram tidak mengeluarkan biaya yang besar untuk promosi (Untari \& Fajariana, 2018). Followers secara tidak langsung menjadi agen pemasar dari Instastory ke Instastory. Hal ini disebabkan karena pengguna Instagram memiliki kebiasaan membuat Instastory setelah melakukan pembelian suatu produk termasuk produk yang dibeli dari Griya Bakery \& Griya Florist. Berbagai alasan diutarakan oleh para informan seperti ingin membantu pemilik usaha, tampilan produknya yang terlihat cantik sehingga wajib dibuatkan unggahan dalam Instastory, serta konsumen yang memang memiliki kebiasaan mengunggah apa yang dibeli hanya untuk memenuhi kepuasan pribadi.

Mengikuti trend, individu pada umumnya selalu ingin mengikuti gaya hidup trend terkini (B. Febriana et al., 2021). Beberapa informan mengungkapkan motivasi mereka ingin membeli produk Griya Bakery karena trend makanan di awal masa new normal adalah bomboloni. Produk yang sedang trend di kalangan masyarakat tentu akan mendapat perhatian lebih di mata konsumen. Keinginan yang besar akan muncul di benak konsumen hingga konsumen benar-benar dapat merasakan langsung produk tersebut.

\section{Perilaku Konsumen Dipengaruhi oleh Faktor Psikologi}

Faktor psikologi menjadi faktor yang paling banyak memengaruhi perilaku konsumen Griya Bakery \& Griya Florist. Kotler dan Armstrong menjelaskan bahwa pilihan pembelian seorang konsumen dipengaruhi oleh empat faktor psikologi utama yaitu 1. Motivasi, 2. Persepsi, 3. Pembelajaran, serta 4. Keyakinan dan sikap (Kotler \& Armstrong, 2008).

\section{1) Motivasi}

Motivasi adalah dorongan yang muncul dari dalam diri atau dari luar diri (lingkungan) yang menjadi faktor penggerak menuju ke arah tujuan yang ingin dicapai (Keren \& Sulistiono, 2019). Pemasaran Instastory yang dilakukan oleh Griya Bakery \& Griya Florist menemukan terdapat lima jenis motivasi. Kelima jenis motivasi tersebut adalah inovasi, promosi, kepuasan untuk diri sendiri, dan penasaran.

Inovasi, merupakan salah satu hal penting yang harus selalu diterapkan oleh sebuah perusahaan jika tidak ingin kehilangan para konsumennya (Ernawati, 2019). Adanya inovasi berhasil menarik konsumen untuk membeli produk. Inovasi produk Griya Bakery yaitu bomboloni dengan penambahan varian rasa yang baru. Griya Bakery juga kerap membuat hampers dengan packaging yang unik pada setiap perayaan satu tahun sekali seperti Idul Fitri, Imlek, dan Natal. Inovasi lainnya yaitu dengan mengkombinasikan antara Griya Bakery dengan 
Griya Florist. Donat bomboloni dan bunga dirangkai dalam satu box. Paket produk ini dianggap cocok untuk dijadikan hadiah oleh konsumen.

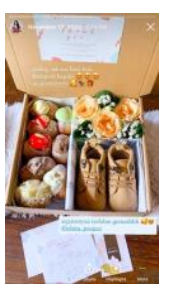

\section{Gambar 5. Instastory Inovasi Griya Bakery \& Griya Florist}

Promosi, setiap promosi yang dilakukan biasanya akan mengakibatkan meningkatnya keputusan pembelian (Sutrisno \& Haryani, 2017). Beberapa konsumen meminta kepada pemilik usaha agar mendapatkan promosi khusus untuk mereka. Promosi yang diminta konsumen biasanya berupa potongan harga atau free ongkir. Griya Bakery \& Griya Florist juga sering memberikan promosi pada hari-hari tertentu. Adanya promosi mendorong konsumen untuk memutuskan pembelian produk. Kesempatan ini diambil konsumen karena promosi hanya hadir pada waktu-waktu tertentu saja.

Kepuasan, perasaan atau mood positif yang dialami seseorang yang mendorongnya untuk melakukan pembelian tidak terencana (Ikanubun et al., 2019). Instastory Griya Bakery \& Griya Florist yang lalu lalang di Instagram konsumen memicu keinginan konsumen untuk membeli produk. Perasaan senang dan puas mereka dapatkan setelah membeli produk. Kepuasan diri lainnya berasal dari kepuasan konsumen yang membeli produk, kemudian produk tersebut diberikan kepada orang lain. Muncul kepuasan tersendiri ketika konsumen dapat memberikan produk kepada orang lain.

Penasaran, Salah satu faktor yang memengaruhi keputusan pembelian makanan adalah keingintahuan seseorang (Prasetiyawan \& Nurhidayah, 2020). Instastory Griya Bakery \& Griya Florist yang diunggah secara konsisten dan rutin setiap harinya mampu menumbuhkan rasa penasaran khususnya calon konsumen yang belum pernah membeli dan merasakan produk dari Griya Bakery \& Griya Florist. Konsumen merasa penasaran sehingga ingin mengetahui seenak apa bomboloni Griya Bakery dan sebagus apa bouqete bunga dari Griya Florist. Rasa penasaran menjadi motivasi pembelian produk Griya Bakery \& Griya Florist.

\section{2) Persepsi}

Iklan kreatif memengaruhi pikiran sehingga dapat memperbesar minat konsumen untuk membeli produk (Khotimah \& Febriansyah, 2018). Persepsi yang terbentuk dari Instastory Griya Bakery \& Griya Florist dipengaruhi oleh beberapa faktor yaitu rangsangan panca indera, tampilan produk menarik, produk ada dalam mindset, dan nilai brand.

Rangsangan panca indera, motivasi terbentuk karena adanya rangsangan yang datang (Dewi et al., 2017). Konten Instastory Griya Bakery \& Griya Florist diakui oleh para informan sangat memanjakan pandangan mata. Instastory Griya Bakery memperlihatkan isian bomboloni yang melimpah kemudian dirobek sehingga menimbulkan keinginan untuk mencoba. Selain konten Griya Bakery, Griya Florist juga menampilkan bouqete bunga yang sangat cantik dilihat oleh mata. Tampilan visual Instastory Griya Bakery \& Griya Florist merangsang reaksi panca indera konsumen khususnya mata. 
Tampilan produk menarik, tampilan paket bomboloni terlihat sangat menarik setelah dibuatkan konten Instastory. Konsumen menyukai tambahan musik yang dipilih dan permainan tone warna yang digunakan dalam Instastory. Produk tidak hanya terlihat bagus dalam Instastory saja, tetapi tampilan pada produk aslinya pun memang bagus dan menarik. Bouqete bunga dari Griya Florist juga memiliki tampilan yang dapat menarik perhatian konsumen. Rangkaian bunga yang indah serta wrapping yang rapi dan cantik dapat menumbuhkan keinginan konsumen untuk membeli bouqete bunga di Griya Florist. Semakin unik desain packaging produk, maka semakin meningkat keinginan konsumen untuk membeli (Fadilla et al., 2019).

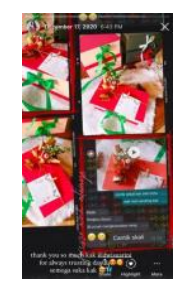

Gambar 1.6 Instastory Tampilan Produk yang Menarik

Produk Ada dalam Mindset, adanya image produk yang baik di ingatan konsumen dapat membuat produk selalu menjadi incaran para konsumen (Oktaviani \& Rustandi, 2018). Konsumen yang sudah pernah membeli produk Griya Bakery \& Griya Florist mengetahui bagaimana kualitas, kelebihan, dan hal-hal yang bagus terhadap produk tersebut. Instastory Griya Bakery \& Griya Florist tidak hanya bagus dilihat secara visual, tetapi mengandung nilai yang hanya dapat dirasakan oleh beberapa informan. Persepsi dan ingatan yang baik tentang produk sudah melekat di dalam pikiran konsumen. Nama Griya Bakery \& Griya Florist akan langsung muncul dari dalam mindset konsumen ketika konsumen membutuhkan bunga hadiah.

\section{3) Pembelajaran}

Konsumen akan menyesuaikan perilakunya dengan pengalamanya dimasa lalu (Marlius, 2017). Penelitian ini mendapatkan dua jenis pembelajaran yang dilakukan oleh para informan yaitu kualitas produk dan membandingkan dengan produk lain.

Kualitas produk, faktor utama yang memengaruhi keputusan pembelian adalah kualitas produk (Fajar Santoso, 2019). Konsumen Griya Bakery \& Griya Florist yang sudah pernah membeli produk sebelumnya dapat menilai bagaimana kualitas produk yang dipesan. Griya Florist mampu menginterpretasikan keinginan konsumen bahkan melebihi ekspektasi konsumen itu sendiri. Menurut informan, kualitas Griya Bakery \& Griya Florist memang bagus sehingga selalu berhasil membuat konsumen selalu merasa puas dan menjaga loyalitas.

Membandingkan, hal yang seeing dibandingkan oleh konsumen Griya Bakery \& Griya Florist adalah harga. Konsumen membandingkan harga produk antara penjual satu dengan penjual lainnya, dan jika konsumen mendapatkan produk yang sesuai dengan pembiayaan yang diinginkan konsumen, maka keputusan pembelian akan terjadi (Isa \& Istikomah, 2018). Selain harga, informan juga membandingkan kualitas produk. Konsumen yang sudah merasa yakin akan dapat memutuskan produk mana yang akan dibeli.

\section{4) Keyakinan dan Sikap}

Sikap dan keyakinan merupakan daya yang kuat dan langsung memengaruhi persepsi serta perilaku konsumen (Dewi et al., 2017). Konten Instastory sering menampilkan proses pembuatan donat. Konsumen yakin akan produk yang dibuat sudah bersih dan higenis karena melihat langsung prosesnya dalam Instastory. Konsumen Griya Florist juga merasa yakin karena produk dan treatment yang dilakukan oleh pemilik usaha menunjukkan totalitas dalam 
memberikan pelayanan terbaik. Konsumen yang merasa yakin menjadi lebih cepat dalam memutuskan sikap untuk melakukan pembelian.

\section{Keputusan Pembelian}

Menurut teori Kotler dan Armstrong, proses keputusan pembelian terdiri dari lima tahap yaitu pengenalan kebutuhan, pencarian informasi, evaluasi alternatif, keputusan pembelian, dan perilaku pascapembelian (Kotler \& Armstrong, 2008). Berdasarkan hasil penelitian, ditemukan lima proses keputusan pembelian yang dilakukan oleh para informan.

Proses Keputusan Pembelian 1 (2-1-2-3-4-5). Tahapan proses keputusan pembelian satu yaitu Pencarian Informasi - Pengenalan Kebutuhan - Pencarian Informasi - Evaluasi Alternatif - Keputusan Pembelian - Pasca Pembelian.

Proses Keputusan Pembelian 2 (1-4-5). Proses keputusan pembelian dua hanya melewati tiga tahap yaitu tahap Pengenalan Kebutuhan - Keputusan Pembelian - Pasca Pembelian.

Proses Keputusan Pembelian 3 (1-2-4-3-5). Pada proses keputusan pembelian tiga, konsumen melewati tahap Pengenalan Kebutuhan - Pencarian Informasi - Keputusan Pembelian - Evaluasi Alternatif - Pasca Pembelian.

Proses Keputusan Pembelian 4 (1-4). Proses keputusan pembelian empat hanya terdapat dua tahapan, Pengenalan Kebutuhan dan tahap yang kedua adalah Keputusan Pembelian.

Proses Keputusan Pembelian 5 (1-2-4-5). Proses keputusan yang terakhir adalah proses keputusan lima. Tahapan dalam proses keputusan lima terdiri dari Pengenalan Kebutuhan Pencarian Informasi - Keputusan Pembelian - Pasca Pembelian.

\section{KESIMPULAN DAN SARAN}

\section{KESIMPULAN}

Hasil penelitian ini menyimpulkan perilaku konsumen yang muncul dalam memutuskan pembelian akibat pemasaran Instastory Griya Bakery \& Griya Florist di era new normal. Perilaku konsumen dipengaruhi oleh beberapa faktor yaitu:

Faktor Budaya, konsumen memutuskan melakukan pembelian akibat pemasaran Instastory Griya Bakery \& Griya Florist yang dipengaruhi oleh faktor budaya dikarenakan adanya motivasi perayaan moment spesial dan sikap saling menolong. Faktor Sosial memengaruhi perilaku konsumen akibat pemasaran Instastory didorong oleh aktivitas media sosial, review konsumen, hubungan sosial, serta peran dan status. Faktor Pribadi, motivasi pembelian konsumen setelah melihat pemasaran Instastory yang dipengaruhi oleh faktor pribadi diantaranya adalah karakteristik dan kepribadian, situasi ekonomi, dan gaya hidup. Faktor Psikologi, pemasaran Instastory membentuk empat karakteristik yang dipengaruhi oleh faktor psikologi yaitu motivasi, persepsi, pembelajaran, serta keyakinan dan sikap. Empat faktor psikologi utama ini mendorong konsumen untuk melakukan pembelian.

Berdasarkan penelitian ini, faktor psikologi memengaruhi perilaku konsumen khususnya keputusan pembelian paling banyak. Pemasaran Instastory Griya Bakery \& Griya 
Florist berhasil memengaruhi psikologi konsumen sehingga mampu mengarahkan konsumen untuk memutuskan melakukan pembelian.

Tahapan keputusan pembelian dalam penelitian ini ditemukan sebanyak lima tahap yaitu:

1. Proses keputusan pembelian 1 yaitu Pencarian Informasi - Pengenalan Kebutuhan Pencarian Informasi - Evaluasi Alternatif - Keputusan Pembelian - Pasca Pembelian.

2. Proses keputusan pembelian 2 meliputi Pengenalan Kebutuhan - Keputusan Pembelian Pasca Pembelian.

3. Proses keputusan pembelian 3 diantaranya adalah Pengenalan Kebutuhan - Pencarian Informasi - Keputusan Pembelian - Evaluasi Alternatif - Pasca Pembelian.

4. Proses keputusan pembelian 4 terdapat Pengenalan Kebutuhan - Keputusan Pembelian.

5. Tahap keputusan pembelian 5 yaitu tahap Pengenalan Kebutuhan - Pencarian Informasi Keputusan Pembelian - Pasca Pembelian.

Tahap keputusan pembelian 2 merupakan proses paling banyak dilakukan oleh konsumen yang menjadi informan, yaitu sebanyak 4 orang dari 11 orang konsumen.

\section{SARAN}

Adapun saran untuk penelitian selanjutnya yaitu peneliti selanjutnya dapat melakukan penelitian serupa dengan menggunakan brand lainnya sebagai objek penelitian. Banyak brand yang menggunakan strategi yang sama yaitu pemasaran melalui Instastory tetapi tidak mendapatkan hasil penjualan yang sama. Memilih brand lain sebagai objek penelitian akan memberikan perbandingan dan hasil yang mungkin saja berbeda terkait perilaku konsumen.

\section{DAFTAR PUSTAKA}

Andarningtyas, N. (2017). Pengguna Instagram di Indonesia capai 45 juta. https://www.antaranews.com/berita/642774/pengguna-instagram-di-indonesia-capai-45juta

Barokah, S., Andina, A. N., \& Anggiany, Z. (2020). Strategi Adaptif Kedai Kopi “ Coffeebreak " Purwokerto. Jurnal Ekonomi, Sosial \& Humaniora Strategi, 01(12), 150-160.

Bohang, F. K. (2019). Pengguna Harian Instagram Stories Tembus Angka 500 Juta. https://tekno.kompas.com/read/2019/01/31/15320087/pengguna-harian-instagramstories-tembus-angka-500-juta

Dewi, S. K., Siburian, P. S., \& Indriastuti, H. (2017). Pengaruh motivasi konsumen , persepsi dan sikap konsumen terhadap keputusan pembelian mobil The influence of consumer motivation, perceptions and consumer attitudes toward car purchase decisions. Manajemen, 9(2), 105-110.

Ernawati, D. (2019). Pengaruh Kualitas Produk, Inovasi Produk Dan Promosi Terhadap Keputusan Pembelian Produk Hi Jack Sandals Bandung. JWM (Jurnal Wawasan Manajemen), 7(1), 17. https://doi.org/10.20527/jwm.v7i1.173

Fadilla, R. I., DWP, I. A., \& Damayanti, R. (2019). Analisis Produk, Brand Image, dan Packaging Terhadap Keputusan Pembelian Konsumen Toko Roti Wonder Bakery di Surakarta. Edunomika, 03(5 (293)).

Fahmi, I. (2016). Perilaku Konsumen Teori dan Aplikasi (M. Sayed (ed.)). Alfabeta.

Fajar Santoso. (2019). Pengaruh Kualitas Makanan dan Persepsi Harga terhadap Keputusan 
Pembelian Kembali melalui Kepuasan Pelanggan Crunchaus Salads di Pakuwon Mall .... Agora, 7(2). http://publication.petra.ac.id/index.php/manajemen-bisnis/article/view/9116 Febriana, B., Pratiwi, N., \& Dwijayanti, R. (2021). Pengaruh Gaya Hidup dan Kelompok Acuan Terhadap Keputusan Pembalian ( Studi Pada Konsumen Kedai Kopi Ruang Temu Kabupaten Tulungagung ). 9(3).

Febriana, M., \& Yulianto, E. (2018). Pengaruh Online Consumer Revew Oleh Beauty Vlogger Terhadap Keputusan Pembelian (Survei Pada Mahasiswi Fakultas Ilmu Administrasi Universitas Brawijaya Angkatan 2014/2015 Dan 2015/2016 Yang Membeli Dan Menggunakan Purbasari Matte Lipstick). Jurnal Administrasi Bisnis (JAB), 58(1), 1-9.

Handika, M. R., Maradona, A. F., \& Darma, G. S. (2018). Strategi Pemasaran Bisnis Kuliner Menggunakan Influencer. Jurnal Manajemen Dan Bisnis, 15(2), 192-203.

Hansudoh, P. Y., Natadjaja, L., \& ... (2021). Perancangan Desain Konten Instagram sebagai Media Informasi Kecantikan. Jurnal DKV http://publication.petra.ac.id/index.php/dkv/article/view/11246

Ikanubun, D., Setyawati, S. M., \& Afif, N. C. (2019). Pengaruh Hedonic Shopping Terhadap Impulse Buying Yang Dimediasi Emosi Positif (Survei Pada Konsumen Toko Fashion di Kota "X"). Jurnal Ekonomi, Bisnis \& Akuntansi. file:///C:/Users/ASUS/Downloads/jurnal/(Davota, 2019) Pengaruh Hedonic Shopping Terhadap Impulse Buying Yang Dimediasi Emosi Positif.pdf

Indah Kencana Putri, L. P. (2019). Perilaku Konsumen Pengguna Instagram di Era Marketing 4.0. Jurnal Manajemen Bisnis, 16(4), 20. https://doi.org/10.38043/jmb.v16i4.2248

Indah, S., Simaremare, V., \& Mujiasih, E. (2018). Hubungan Antara Customer Value Dengan Impulse Buying Produk Fashion Pada Mahasiswi Angkatan 2017 Psikologi Universitas Diponegoro. Empati, 7(4), 162-167.

Indika, D. R., \& Jovita, C. (2017). Media Sosial Instagram Sebagai Sarana Promosi Untuk Meningkatkan Minat Beli Konsumen. Jurnal Bisnis Terapan, 1(01), 25-32. https://doi.org/10.24123/jbt.v1i01.296

Isa, M., \& Istikomah, R. (2018). Analisi Perilaku Konsumen dalam Keputusan Pembelian Makanan di Kota Surakarta. Oxford Art Online, 98-110. https://doi.org/10.1093/gao/9781884446054.article.t082385

Jayani, D. H. (2020). 10 Media Sosial yang Paling Sering Digunakan di Indonesia. https://databoks.katadata.co.id/datapublish/2020/02/26/10-media-sosial-yang-palingsering-digunakan-di-indonesia

Keren, K., \& Sulistiono, S. (2019). Pengaruh Motivasi, Budaya, dan Sikap Konsumen Terhadap Keputusan Pembelian Produk Indomie. Jurnal Ilmiah Manajemen Kesatuan, 7(3), 319-324. https://doi.org/10.37641/jimkes.v7i3.284

Khotimah, K., \& Febriansyah, F. (2018). Pengaruh kemudahan penggunaan, kepercayaan konsumen dan kreativitas iklan terhadap minat beli konsumen online-shop. Jurnal Manajemen Strategi Dan Aplikasi Bisnis, 1(1), 19-26. https://doi.org/10.36407/jmsab.v1i1.16

Kotler, P., \& Armstrong, G. (2008). Prinsip-prinsip Pemasaran (A. Maulana, D. Barnadi, \& W. Hardani (eds.); 12 Jilid 1). Erlangga.

Lassa, J. A. (2020). Response masyarakat sipil atas norma 'adaptasi kebiasaan baru (Issue August).

Luthfianto, D. (2017). Pengaruh kualitas layanan dan Gaya Hidup Terhadap Keputusan Pembelian Cafe Jalan Korea. Jurnal Ekonomi Bisnis, 22(1), 14-25. ejurnal.gunadarma.ac.id

Marlius, D. (2017). Keputusan Pembelian Berdasarkan Faktor Psikologis dan Bauran Pemasaran PT. Intercom Mobilindo Padang. Jurnal Pundi, 549(01), 40-42.

Mulyadi, N. (2013). Perilaku Konsumen Dalam Perspektif Kewirausahaan. Alfabeta. 
Oktaviani, F., \& Rustandi, D. (2018). Implementasi Digital Marketing dalam Membangun Brand Awareness. PRofesi Humas : Jurnal Ilmiah Ilmu Hubungan Masyarakat, 3(1), 1. https://doi.org/10.24198/prh.v3i1.15878

Perdana, R. C., Agustino, M. R., Hartawan, D., Suyoso, Y. A., \& Sari, R. (2020). Adaptasi dan Kebiasaan Baru Human Resource Department di Masa Pandemik Covid-19. Business Innovation and Entrepreneurship Journal, 2(3), 201-204. https://doi.org/10.35899/biej.v2i3.138

Prasetiyawan, A. A., \& Nurhidayah, S. M. (2020). Analisis Faktor-Faktor Keputusan Pembelian Makanan Online Muslim Millenial. Academica Journal of Multidisciplinary Studies, 4(December), 225-244.

Safitri, Y., \& Ramadanty, S. (2019). Strategi Kampanye Public Relations melalui Peran Key Opinion Leader di Indonesia. Ikatan Sarjana Komunikasi Indonesia, 2(2), 88-96.

Setianto, G., Wartini, S., Manajemen, J., \& Ekonomi, F. (2017). Pengaruh Bukti Fisik dan Empati Terhadap Loyalitas Konsumen Melalui Kepuasan Konsumen. Management Analysis Journal, 6(4). http://maj.unnes.ac.id

Sholeh, M., Suraya, \& Zaitunah, A. (2019). Pemanfaatan Media Sosial Sebagai Media Promosi. Jurnal Common, 3(1), 71-80. https://doi.org/10.34010/common.v3i1.1950

Statista. (2017). Jumlah Pengguna Aktif Harian Snapchat dan Instagram Stories. https://databoks.katadata.co.id/datapublish/2017/05/19/pengguna-instagram-storiesungguli-snapchat

Sugiyono. (2017). Metode Penelitian Kualitatif Untuk peneliti yang bersifat: eksploratif, enterpretif dan konstruktif. Alfabeta.

Sugiyono. (2019). Metode Penelitian Kuantitatif Kualitatif dan R\&D (Sutopo (ed.)). Alfabeta. Suryani, T. (2008). Perilaku Konsumen Implikasi Pada Strategi Pemasaran,. Graha Ilmu.

Sutrisno, N., \& Haryani, A. D. (2017). Influence of Brand and Product Quality on Customer'S Buying Decision in South Cikarang Bekasi Regency. Jurnal Lentera Bisnis, 6(1), 85. https://doi.org/10.34127/jrlab.v6i1.169

Syafirah, Mananeke, L., \& Jorie Rotinsulu, J. (2017). Pengaruh Faktor-Faktor Per ... 245 Jurnal EMBA, 5(2), 245-255.

Taib, Z., \& Supriana, T. (2020). Perspektif Ekonomi Pada Era New Normal Pasca Covid-19. Akses: Jurnal Ekonomi Dan Bisnis, 15(2), 108-118.

Towoliu, J. E. ., \& Tumbuan, W. J. F. . (2017). Pengaruh Faktor Pribadi dan Faktor Keluarga Terhadap Keputusan Pembelian di rumah Makan Waroeng Tepi Laut, Manado. Jurnal EMBA, 5(2), 308-322.

Untari, D., \& Fajariana, D. E. (2018). Strategi Pemasaran Melalui Media Sosial Instagram (Studi Deskriptif Pada Akun @Subur_Batik). Widya Cipta - Jurnal Sekretari Dan Manajemen, 2(2), 271-278. http://ejournal.bsi.ac.id/ejurnal/index.php/index/search/search?query=strategi+pemasara n\&searchJournal $=\&$ authors $=\&$ title $=\&$ abstract $=\&$ galleyFullText $=\&$ suppFiles $=\&$ dateFro mMonth $=\&$ dateFromDay $=\&$ dateFrom Year $=\&$ dateToMonth $=\&$ dateToDay $=\&$ dateToYe ar=\&dateToHour $=23 \&$ dateTo

Wiridjati, W., \& Roesman, R. R. (2018). Fenomena Penggunaan Media Sosial Dan Pengaruh Teman Sebaya Pada Generasi Milenial Terhadap Keputusan Pembelian. Jurnal Manajemen Dan Pemasaran Jasa, 11(2), 275. https://doi.org/10.25105/jmpj.v11i2.2950 